\title{
Comparison of Mini-squats and Straight Leg Raises in Patients with Knee Osteoarthritis: A Randomized Controlled Clinical Trial
}

\author{
Diz Osteoartritli Hastalarda Mini Squat ve Düz Bacak Kaldırma Egzersizlerinin \\ Karşılaştırılması: Randomize Kontrollü Klinik Çalışma
}

\author{
Arzu DAŞKAPAN, ${ }^{1}$ Bahar ANAFOROĞLU, ${ }^{2}$ Nihan ÖZÜNLÜ PEKYAVAŞ, ${ }^{2}$ Emine Handan TÜZÜN, ${ }^{1}$ \\ Sacide NUR COŞAR, ${ }^{3}$ Metin KARATAŞ ${ }^{3}$ \\ ${ }^{1}$ Department of Physiotherapy and Rehabilitation, Kirıkkale University, Faculty of Health Sciences, Ankara, Turkey \\ ${ }^{2}$ Department of Physiotherapy and Rehabilitation, Başkent University, Faculty of Health Sciences, Ankara, Turkey \\ ${ }^{3}$ Department of Physical Medicine and Rehabilitation, Medical Faculty of Başkent University, Ankara, Turkey
}

\begin{abstract}
Objectives: In this study, we aimed to compare the effects of the straight leg raise exercise (SLRE) and mini squat exercise (MSE) on pain intensity, performance, muscle strength, physical function and balance in patients with knee osteoarthritis (OA).

Patients and methods: Forty female patients (mean age $59.93 \pm 10.61$ years; range 30-65 years) who were admitted to Başkent University Hospital between February 2009 and February 2010 with bilateral knee OA were included in this randomized controlled double-blind clinical trial. The patients were assigned into two groups, including SLRE and MSE. Both exercise groups were scheduled for a threeweek program of five sessions per week. Both groups also received an electrotherapy program in each session. Knee pain using the visual analog scale (VAS), physical performance using Timed Up and Go (TUG) Test, isokinetic quadriceps and hamstring muscle strengths using Cybex II, static balance using SportKAT 3000, physical function using Knee Injury and Osteoarhtritis Outcome Score-Physical Function Short Form (KOOS-PS) were assessed at baseline, at treatment end, and one month after treatment end.
\end{abstract}

Results: No significant difference was found in static balance testing parameters after exercise program (EP) $(p=0.659)$ and during follow-up period $(p=0.327)$ between the groups. There was no significant difference in KOOS-PS scores after EP $(p=0.398)$ and during follow-up $(p=0.201)$ between SLRE and MSE groups. There was no significant difference in VAS scores after EP $(p=0.149)$, however significant difference was found during follow-up $(p=0.030)$ between SLRE and MSE groups. Mini squat exercise group had significantly higher TUG scores and higher right knee extensor torque at $60 \% \mathrm{sec}(p=0.024), 90 \%$ sec $(p=0.003)$, $120 \%$ sec $(p=0.005)$ and $180 \% \mathrm{sec}(p=0.017)$ compared to the SLRE group at the end of EP.

Conclusion: Further studies are required including long-term follow-up and the evaluation criteria of the effectiveness of SLRE and MSE after this period.

Key words: Knee; mini squat exercises; osteoarthritis; straight leg raise exercises.
Amaç: Bu çalışmada diz osteoartritli (OA) hastalarda ağrı şiddeti, performans, kas kuvveti, fiziksel fonksiyon ve denge üzerine düz bacak kaldırma egzersizi (DBKE) ve mini çömelme egzersizinin (MÇE) etkinliği karşılaştırıldı.

Hastalar ve yöntemler: Şubat 2009-Şubat 2010 tarihleri arasında iki taraflı diz OA yakınması ile Başkent Üniversitesi Hastanesi'ne başvuran, 40 kadın hasta (ort. yaş $59.93 \pm 10.61$ yıl; dağııım 30-65 yıl) bu randomize kontrollü, çift-kör klinik çalışmaya dahil edildi. Hastalar DBKE ve MÇE olmak üzere iki gruba ayrıldı. Her iki egzersiz grubu haftada bes seanstan oluşan toplam üç haftalık bir programa dahil edildi. İki grup da her seansta elektroterapi programı aldı. Görsel analog ölçeği (GAÖ) ile diz ağrısı, Zamanlı Kalk-Yürü (ZKY) testi ile fiziksel performans, Cybex II ile izokinetik kuadriseps ve hamstring kas kuvveti, Spor KAT 3.0 ile statik denge, Diz İncinme ve Osteoartrit Sonuç Skoru-Fiziksel Fonksiyon KIsa Formu (KOOS-PS) ile fiziksel fonksiyon başlangıçta, tedavi sonrasında ve tedaviden bir ay sonra değerlendirildi.

Bulgular: Statik denge parametreleri göz önünde bulundurulduğunda egzersiz programı $(E P)$ sonrası $(p=0.659)$ ve takip döneminde $(p=0.327)$ gruplar arası anlamlı fark bulunmadı. Egzersiz programı sonrası $(p=0.398)$ ve takip döneminde $(p=0.201)$ DBKE ve MÇE grupları arasında KOOSPS skorları açısından anlamlı fark bulunmadı. Ayrıca GAÖ skorları açısından EP sonrasında $(p=0.149)$ DBKE ve MÇE grupları arası anlamlı fark bulunmamasına rağmen takip döneminde $(p=0.030)$ anlamlı fark bulundu. Mini çömelme egzersiz grubu, DBKE grubuna kıyasla, EP sonunda anlamlı düzeyde yüksek ZKY testi skorları ve $60 \%$ sn ( $p=0.024), 90 \%$ sn $(p=0.003), 120 \%$ sn $(p=0.005)$ ve $180 \%$ sn'de $(p=0.017)$ daha yüksek sağ izokinetik diz ekstansör kas kuvvetine sahipti.

Sonuç: Uzun dönemli takipleri içeren ve bu periyottan sonra DBKE ve MÇE'nin etkinliğini değerlendirebilecek kriterleri kapsayan başka çalışmalara gereksinim vardır.

Anahtar sözcükler: Diz; mini çömelme egzersizi; osteoartrit; düz bacak kaldırma egzersizi.

Received: January 17, 2012 Accepted: June 21, 2012

Correspondence: Bahar Anaforoğlu, P.T., PhD. Başkent üniversitesi, Sağlık Bilimleri Fakültesi Fizyoterapi ve Rehabilitasyon Bölümü, 06810, Etimesgut, Ankara, Turkey. Tel: +90 312 - 2466673 e-mail: anaforoglub@hotmail.com

(O2013 Turkish League Against Rheumatism. All rights reserved. 
Osteoarthritis (OA) is the most common form of arthritis and has one of the highest rates of comorbidity ${ }^{[1,2]}$ Osteoarthritis of the knee typically affects women more than men and has a prevalence between $10-15 \%$ at age 35 and $35-45 \%$ at age $65 .{ }^{[3]}$ Since it is currently the most prevalent chronic condition among women, OA warrants serious concern. ${ }^{[4]}$

The knee is the most frequently involved joint in $\mathrm{OA} \cdot{ }^{[5]}$ It has been demonstrated that muscle strength and functional capacity are reduced in patients dealing with this malady, ${ }^{[6,7]}$ and the functional consequences of knee OA are associated with lower extremity mobility limitations. ${ }^{[8,9]}$ A deterioration in quadriceps function may cause impaired balance and gait, thus reducing mobility and function in patients with knee OA. ${ }^{[10]}$

The primary goals for OA therapy are pain relief, maintenance of joint integrity, improvement in functional status, and a decrease in deformity and instability. ${ }^{[1]}$ Active modalities such as muscle strengthening exercises have been found to be effective in reducing pain and disability as well as in improving the quality of life and performance of functional tasks in patients with knee OA. Exercises to improve muscle strength and joint mobility often require a considerable commitment by patients over long periods of time. ${ }^{[12]}$ However, their efficacy has been proven as previous studies have found that exercise had a smallto-moderate effect on pain, quadriceps strength, and physical function. ${ }^{[13-16]}$

Straight leg raises and mini-squats are very commonly prescribed to increase the strength and control of the knee muscles. ${ }^{[17]}$ Straight leg raises are a movement with a free distal extremity that improves the strength of the knee muscles and protects the knee joint. Mini-squats target only the knee joint and are performed under weight-bearing or simulated weightbearing conditions with a fixed distal extremity.

According to the results of previous studies, it seems that there is no general agreement regarding the effectiveness of the therapeutic effect of these two exercises; therefore, this study has been designed to investigate the effects of straight leg raises and minisquats on patients with knee OA.

\section{PATIENTS AND METHODS}

A randomized, controlled double-blind clinical trial was performed to compare the effects of two interventions: straight leg raises exercise (SLRE) and mini-squat exercise (MSE). This study was approved by the ethics committee of Başkent University in Ankara,
Turkey, and all patients gave their informed consent before being included. The participants were diagnosed according to the radiographic assessment of their tibiofemoral joints by two physiatrists. The patients were assigned at random to the one of the two exercise groups using an online random allocation software program (GraphPad Software QuickCalcs, GraphPad Software Inc., La Jolla, California, USA). This free online calculator offers a simple random allocation list broken down into equal-sized groups after the number of the subjects in each group and the number of the groups are entered.

One physiotherapist evaluated the patients, and another assigned the patients to one of the two exercise routines. These two physiotherapists and all participants were blind to the groups in order to provide a double-blind procedure.

The patients in this study were recruited from the Department of Physical Therapy at University Hospital between February 2009 and February 2010. Participants needed to be females between the ages of 30 and 65 years old with bilateral knee OA of grade 2 or 3 on the Kellgren-Lawrence classification system as identified via a plain X-ray examination of the tibiofemoral joint in order to meet the inclusion criteria. $^{[18]}$

Subjects who reported a history of another deformity, those who had undergone surgery on their lower limbs, or those who had problems cooperating with the study requirements were excluded from the study.

A total of 57 patients were enrolled in this study. Of these, 12 subjects did not meet the inclusion criteria, three refused to participate, and two dropped out of the study due to personal reasons. The remaining 40 subjects completed the full course of the study after being randomly assigned to the mini-squat $(n=20)$ or straight leg raises group $(n=20)$ (Figure 1).

Scores from the visual analog scale (VAS) for pain were used as the basis for calculating this study's power. A power analysis indicated that 24 subjects for each group were needed [common standard deviation $( \pm S D)=0.43]$ with $80 \%$ power and a $5 \%$ type 1 error. The power analysis of our study showed a power of $73 \%$ with pain intensity as the primary outcome.

The subjects received physical therapy modalities including a hot pack, transcuteneous electrical stimulation (TENS), and ultrasound (US) for 15 days during their exercise program. 


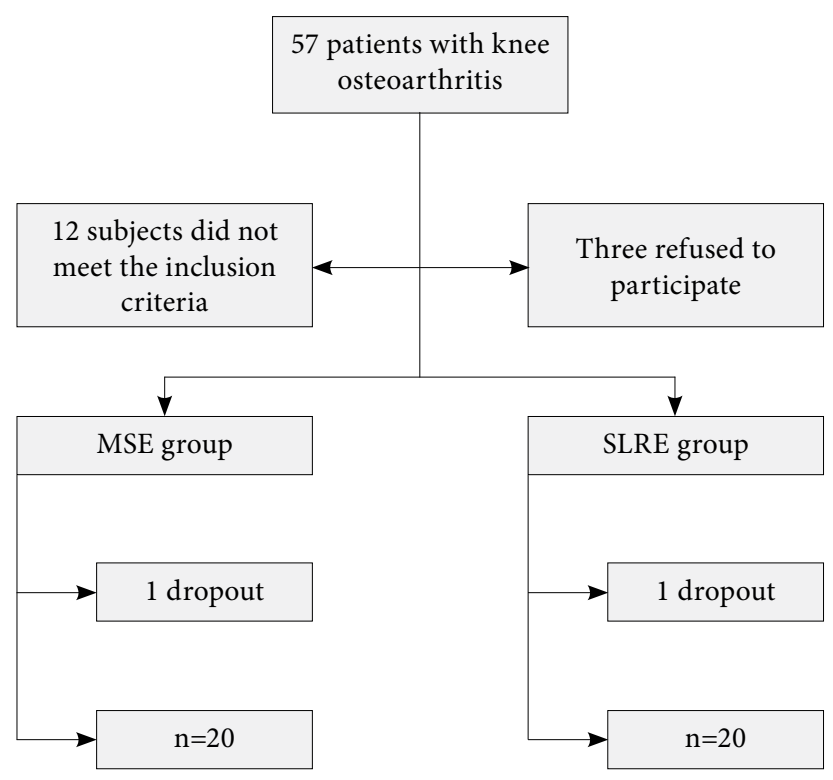

Figure 1. Flowchart of patient selection.

The program, which featured SLRE and MSE, was prepared according to a study conducted by Bakhtiary and Fatemi ${ }^{[17]}$ Patients in the SLRE group did these exercises for three weeks (20 times twice daily) with an extended knee. The number of exercises was increased by five every two days so that by the end of the program (day 15), the subjects were performing 55 SLRE twice a day. To perform these exercises, the subjects were in a supine position with their hip and knee flexed in both extremities while the soles of their feet were on the treatment table.

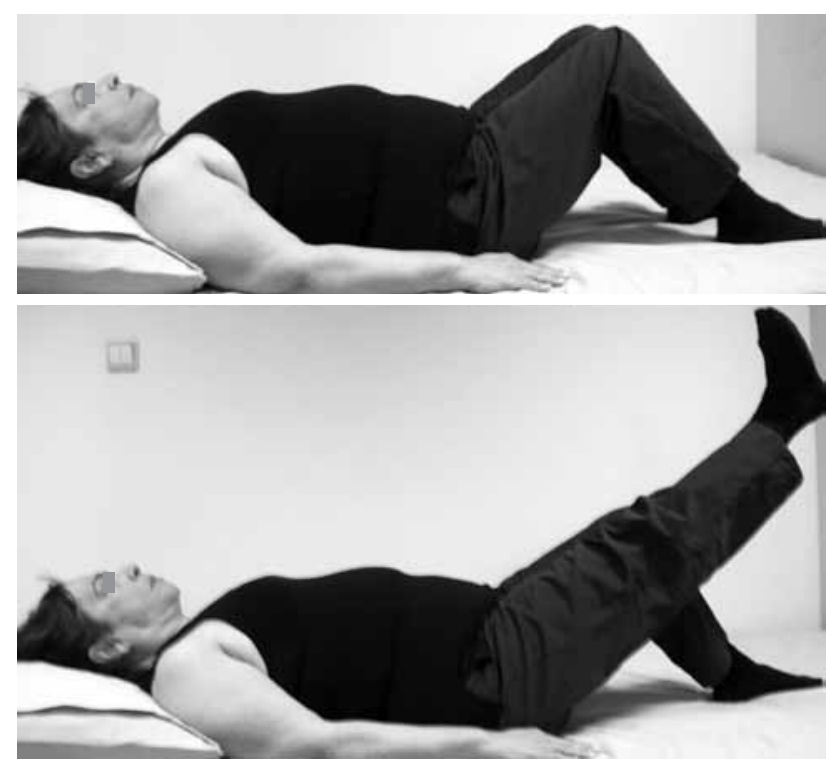

Figure 2. Straight leg raise exercise.
They were asked to extend one leg and hold it with an extended knee until $45^{\circ}$ hip flexion for threefour seconds. Then they let it down for a three-four second rest (Figure 2).

The patients in the MSE group also followed an exercise program for three weeks (20 times twice daily). The increase in the exercise routine was conducted in the same way as the other group so that by the end of the program (day 15), the participants were performing 55 mini-squats twice a day. To perform the mini-squats, the subjects were asked to stand on the lower extremity to be exercised and hold onto a stable surface using their hands. Meanwhile the other lower extremity was in $90^{\circ}$ hip and knee flexion. The subject was then ordered to flex the extended knee $15-20^{\circ}$ and hold this position for threefour seconds. Then they brought it to full extension and remained in that position for a three-four second rest (Figure 3).

The patients were asked to carry out the exercises 55 times twice a day for four weeks after their exercise program had ended.

Patient measurements, which included knee femoral pain, physical performance, isokinetic quadriceps and
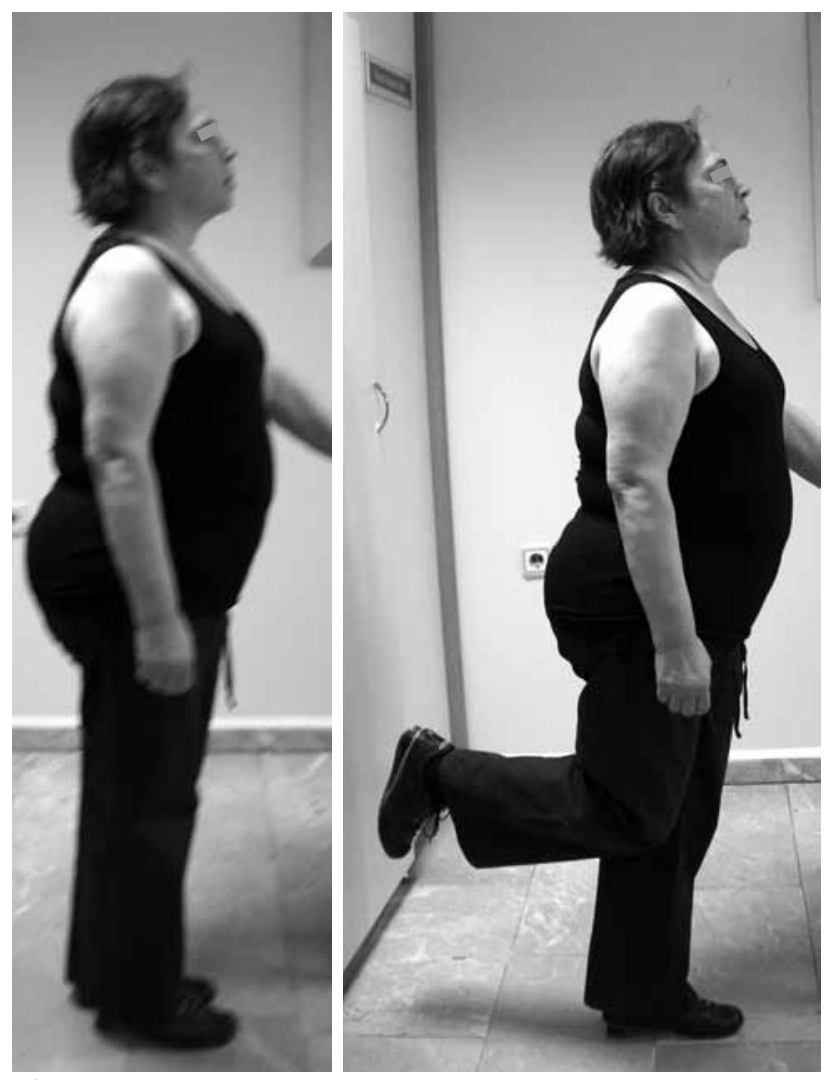

Figure 3. Mini-squat exercise. 
hamstring muscle strength, static standing balance, and physical function, were performed before the first treatment session, at the end of the exercise program, and at the fourth week following the end of the program.

Knee pain was measured using a VAS on which the patients could grade their pain from " 0 " (no pain at all) to " 10 " (the most severe pain imaginable).

The Timed Up and Go (TUG) test was incorporated to assess functional mobility. It is a timed test in which the subjects rise from a chair (seat height $45 \mathrm{~cm}$ ), walk three meters, turn around, and return to a seated position in the chair. The subjects performed two trials, and the average time to complete the task was recorded. They were permitted to use the arms of the chair as they rose from the chair and as they returned to a seated position. ${ }^{[19]}$ The TUG test has excellent reliability and validity and has previously been used to examine outcomes in persons with knee OA. ${ }^{[20]}$

An isokinetic dynamometer (Cybex 770 Norm, Cybex International Inc., a division of Lumex Inc, Ronkonkoma, New York, USA) was used to evaluate the muscle strength of the quadriceps and hamstring muscles, and it was calibrated at the beginning of each evaluation. The patients were seated with their hips and knees flexed at $90^{\circ}$. The axis of the dynamometer was positioned parallel to the lateral femoral condyle. The isokinetic strength of the quadriceps and hamstring muscle was tested at constant angular velocities of $90 \%$ sec and $120 \%$ sec with five repetitions at each velocity. A 30 -second rest period was allowed between sets. The tests were conducted on both knees, and before beginning, trial repetitions were allowed for orientation. During the tests, the patients were verbally encouraged.

The SportKAT 3000 kinesthetic ability trainer (Breg, Inc., Vista, California, USA) was used to assess static standing balance. The system involves a centrally pivoted balance platform. When the platform deviates from the reference position, this information is transmitted to the computer system via a tilt sensor connected to the front of the platform unit. On the computer screen, a circle represents the balance platform, and the center of the circle represents the reference position. The circle is divided into four quadrants referred to as "left front," "left back," "right front," and "right back," and an individual balance score is recorded for each of these sections. The position of the balance platform relative to the horizontal plane is represented by a cursor (red X) on the test screen. For each quadrant, the computer system measures the distance from the cursor to the reference position every tenth of a second. The testing system generates seven different parametric measurements, and the sum of the scores for each quadrant in a test period is recorded as the overall balance index score. This reflects the person's ability to keep the platform at or near the reference position. The balance index scores range from 0 to 6000 with lower values indicating better performance.

During the static standing balance testing, the subjects were asked to maintain a bilateral stance and to keep their eyes open while concentrating on the " $X$ " at eye level on a height-adjusted computer screen one meter in front of them. Three trials of testing, each lasting 30 seconds with a 10 -second rest between them, were performed.

Physical function was evaluated with the Turkish version of the Knee Injury and Osteoarthritis Outcome Score Physical Function short form (KOOS-PS), a seven-item instrument measuring physical function derived from the function, daily living and function, and sports and recreational activity subscales of the KOOS. As with the KOOS, it is intended to elicit people's opinions about the difficulties they experience with activity due to problems with their knee. Patients are scored by totaling their responses to the seven items of the KOOS-PS. An interval score ranging from 0 to 100 , with zero representing no difficulty, is obtained by using the published conversion chart. ${ }^{[21,22]}$

\section{Statistical analysis}

The Statistical Package for the Social Sciences, (SPSS Inc., Chicago, Illinois, USA) version 15.0 software program for Windows was used to perform statistical analyses. A chi-square test was used to test for the dominant foot in the descriptive statistics, and the Friedman test was used for statistical analyses within both groups for all parameters. Pairwise comparisons were then assessed using the Wilcoxon signed-rank test for repeated measures with a Bonferroni adjustment. The Mann-Whitney U test was used for analyzing the differences between groups at the end of treatment and control phases. A $p$ value of $<0.05$ was considered to be statistically significant.

\section{RESULTS}

There were no statistically significant differences regarding the demographic and clinical parameters between the MSE group and SLRE group at baseline ( $>0.05$; Table 1). 
Table 1. Descriptive statistics of the participants

\begin{tabular}{|c|c|c|c|c|c|c|c|}
\hline \multirow[b]{2}{*}{ Demographic data } & \multicolumn{3}{|c|}{ MSE group $(n=20)$} & \multicolumn{3}{|c|}{ SLRE group $(n=20)$} & \multirow[b]{2}{*}{$p$} \\
\hline & Minimum & Maximum & Median & Minimum & Maximum & Median & \\
\hline Age (years) ${ }^{* *}$ & 40.00 & 78.00 & 57.50 & 35.00 & 80.00 & 59.50 & 0.456 \\
\hline Height $(\mathrm{m})^{* *}$ & 1.50 & 1.71 & 1.60 & 1.44 & 1.70 & 1.58 & 0.098 \\
\hline Mass $(\mathrm{kg})^{* *}$ & 60.00 & 95.00 & 77.00 & 58.00 & 110.00 & 75.00 & 0.968 \\
\hline BMI $\left(\mathrm{kg} / \mathrm{m}^{2}\right)^{\star *}$ & 40.06 & 24.02 & 29.32 & 24.44 & 46.99 & 30.75 & 0.499 \\
\hline Dominant foot ${ }^{* * *}$ & & $100 \% \mathrm{R}$ & & & $\begin{array}{l}90 \% \mathrm{R} \\
10 \% \mathrm{~L}\end{array}$ & & $<0.001^{\star}$ \\
\hline
\end{tabular}

In addition, there were no differences in the static balance testing parameters after the exercise program $(\mathrm{p}=0.659)$ or at follow-up $(\mathrm{p}=0.327)$ (Table 2, 3). Moreover, these same parameters did not change in the two groups with treatment $(\mathrm{p}=0.117 ; \mathrm{p}=0.737)$ and at follow-up $(\mathrm{p}=0.881 ; \mathrm{p}=0.911)$.

The VAS and KOOS-PS scores were lower in the MSE group $(\mathrm{p}<0.001)$ and SLRE group $(\mathrm{p}<0.001)$ after the exercise program (Table 4). Only the KOOS-PS scores of the MSE group were significantly different in the follow-up period compared with what was found after the exercise program ( $\mathrm{p}=0.004$; Table 5). There were no significant differences in the KOOS-PS scores after the exercise program $(\mathrm{p}=0.398)$ and at followup $(\mathrm{p}=0.201)$ between the two groups (Table 2, 3). Furthermore, there were no significant differences in the VAS scores after the exercise program $(\mathrm{p}=0.149)$, but a significant difference was found at follow-up $(p=0.030)$ between the two exercise groups (Table 2, 3).

There was also a significant difference in the TUG test scores in the MSE group after the exercise routine $(\mathrm{p}<0.001)$ and at follow-up $(\mathrm{p}=0.015)$ (Table 5), and the TUG scores improved significantly after exercise compared with the patients' baseline scores $(p<0.001)$. However, the follow-up TUG scores were not significantly different in the MSE group when compared with the scores before and after the exercise program ( $\mathrm{p}=0.640$; Table 5).

In the MSE group, the peak torque for concentric isokinetic right knee extension at $60 \% \mathrm{sec}(\mathrm{p}=0.007)$, $90 \% \mathrm{sec}(\mathrm{p}<0.001), 120 \% \mathrm{sec}(\mathrm{p}=0.003)$ and $180 \% \mathrm{sec}$ $(\mathrm{p}=0.006)$ and the peak torque for concentric isokinetic left knee extension at $90^{\circ}(\mathrm{p}=0.018), 120^{\circ} \mathrm{sec}(\mathrm{p}=0.017)$ and $180 \% \mathrm{sec}(\mathrm{p}=0.005)$ increased significantly after the exercise program, but the other concentric isokinetic knee strength parameters did not change ( $p>0.05)$. At follow-up, except for the significant decline in the peak torque for concentric isokinetic extension in both knees at $120^{\circ}(\mathrm{R}, \mathrm{p}=0.001 ; \mathrm{L}, \mathrm{p}=0.025)$ and the peak torque for concentric isokinetic right knee extension at $90 \% \mathrm{sec}$ $(\mathrm{p}=0.008)$ and $180 \% \mathrm{sec}(\mathrm{p}=0.006)$, the other torques did not change significantly when compared with the MSE group after the exercise program ( $>0.05)$ (Table 5).

In the the group that did SLRE, no significant differences were observed in the peak torque for concentric isokinetic extension in both knees at all degrees after the exercise program and at follow-up ( $>0.05$; Table 5). However, a significant difference was found in the peak torque for concentric isokinetic flexion in both knees torque at $90 \% \mathrm{sec}(\mathrm{R}, \mathrm{p}=0.005, \mathrm{~L}$, $\mathrm{p}=0.018$ ) and the torque for left side flexion at $120 \% \mathrm{sec}$ $(\mathrm{p}=0.049)$ at follow-up (Table 5).

The MSE group had significantly lower TUG test scores and higher torque for right knee extension at $60 \% \mathrm{sec}(\mathrm{p}=0.024), 90 \% \mathrm{sec}(\mathrm{p}=0.003), 120 \% \mathrm{sec}(\mathrm{p}=0.005)$ and $180 \% \mathrm{sec}(\mathrm{p}=0.017)$ than the SLRE group at the end of the exercise program (Table 2,3).

\section{DISCUSSION}

Various types of exercises have been commonly used and are effective nonpharmacological treatment modalities for patients with lower limb OA. ${ }^{[23,24]} \mathrm{A}$ more recent study accentuated the fact that exercise is the core component for the management of knee $\mathrm{OA} \cdot{ }^{[25]}$ Strengthening exercises are effective in reducing pain and disability, improving the quality of life, and slowing disease progression for all patients with OA, but they are especially useful for patients with knee $\mathrm{OA} .{ }^{[23,26]}$ In addition, isometric, isotonic, isokinetic, concentric, and eccentric exercises can be performed in an open or closed kinetic chain manner to increase muscle strength. ${ }^{[25]}$

Our study evaluated the effectiveness of straight leg raises or mini-squats when they were added to 
Table 2. Differences between groups at the end of exercise program

\begin{tabular}{|c|c|c|c|c|c|c|c|}
\hline & \multicolumn{3}{|c|}{ MSE group } & \multicolumn{3}{|c|}{ SLRE group } & \multirow[b]{2}{*}{$p$} \\
\hline & Min. & Max. & Med. & Min. & Max. & Med. & \\
\hline TUG (sn) & 4.81 & 9.97 & 6.82 & 5.00 & 13.81 & 8.52 & $0.015^{*}$ \\
\hline VAS $(\mathrm{cm})$ & 0.00 & 8.00 & 1.50 & 0.00 & 10.00 & 3.00 & 0.149 \\
\hline KOOS-PS & 25.00 & 500.00 & 200.00 & 0.00 & 700.00 & 312.50 & 0.398 \\
\hline SportKAT & 170.00 & 3518.00 & 498.50 & 131.00 & 6744.00 & 563.00 & 0.659 \\
\hline $\mathrm{R} \operatorname{EXT} 60 \% \mathrm{sec}$ & 20.00 & 71.00 & 43.00 & 11.00 & 62.00 & 25.00 & $0.024^{*}$ \\
\hline L EXT $60^{\circ} / \mathrm{sec}$ & 20.00 & 72.00 & 34.50 & 12.00 & 64.00 & 34.00 & 0.398 \\
\hline R FLEX $60^{\circ} / \mathrm{sec}$ & 5.00 & 53.00 & 12.00 & 1.00 & 33.00 & 13.50 & 0.678 \\
\hline L FLEX $60^{\circ} / \mathrm{sec}$ & 1.00 & 37.00 & 12.00 & 1.00 & 28.00 & 16.00 & 0.445 \\
\hline $\mathrm{R} \mathrm{EXT} 90^{\circ} / \mathrm{sec}$ & 14.00 & 61.00 & 37.50 & 0.00 & 50.00 & 20.00 & $0.003^{*}$ \\
\hline L EXT $90 \%$ sec & 8.00 & 56.00 & 31.50 & 11.00 & 53.00 & 27.00 & 0.192 \\
\hline R FLEX $90^{\circ} / \mathrm{sec}$ & 1.00 & 39.00 & 13.00 & 0.00 & 24.00 & 8.00 & 0.142 \\
\hline L FLEX $90^{\circ} / \mathrm{sec}$ & 0.00 & 31.00 & 8.00 & 1.00 & 27.00 & 8.00 & 0.904 \\
\hline $\mathrm{R} \operatorname{EXT} 120^{\circ} / \mathrm{sec}$ & 12.00 & 54.00 & 36.00 & 0.00 & 45.00 & 20.00 & $0.005^{*}$ \\
\hline $\mathrm{L} \mathrm{EXT} 120 \% \mathrm{sec}$ & 5.00 & 46.00 & 31.00 & 9.00 & 45.00 & 26.00 & 0.174 \\
\hline R FLEX $120 \% \mathrm{sec}$ & 1.00 & 39.00 & 8.00 & 0.00 & 18.00 & 26.00 & 0.758 \\
\hline L FLEX $120 \%$ sec & 1.00 & 24.00 & 10.50 & 0.00 & 18.00 & 10.00 & 0.445 \\
\hline R EXT $180^{\circ} / \mathrm{sec}$ & 7.00 & 65.00 & 30.50 & 0.00 & 20.00 & 7.00 & $0.017^{\star}$ \\
\hline L EXT $180^{\circ} / \mathrm{sec}$ & 1.00 & 38.00 & 23.00 & 8.00 & 34.00 & 18.50 & 0.114 \\
\hline R FLEX $180 \%$ sec & 1.00 & 31.00 & 7.00 & 9.00 & 42.00 & 22.00 & 0.659 \\
\hline L FLEX $180^{\circ} / \mathrm{sec}$ & 1.00 & 20.00 & 6.00 & 1.00 & 15.00 & 4.50 & 0.547 \\
\hline
\end{tabular}

a traditional physical therapy program in patients with knee OA. Both types of exercises exhibited that they can be used to reduce pain and disease-related functional losses in OA. However, after completing an outpatient physical therapy program, continuation of these beneficial effects depends on the patient's

Table 3. Differences between groups at follow-up

\begin{tabular}{|c|c|c|c|c|c|c|c|}
\hline & \multicolumn{3}{|c|}{ MSE group } & \multicolumn{3}{|c|}{ SLRE group } & \multirow[b]{2}{*}{$p$} \\
\hline & Min. & Max. & Med. & Min. & Max. & Med. & \\
\hline TUG (sn) & 5.76 & 10.00 & 7.25 & 5.48 & 19.80 & 9.10 & 0.327 \\
\hline VAS $(\mathrm{cm})$ & 0.00 & 7.00 & 1.00 & 0.00 & 10.00 & 2.87 & $0.030^{*}$ \\
\hline KOOS-PS & 0.00 & 500.00 & 200.00 & 0.00 & 700.00 & 292.50 & 0.201 \\
\hline SportKAT & 88.00 & 3791.00 & 424.00 & 88.00 & 2492.00 & 844.15 & 0.327 \\
\hline $\mathrm{R} \operatorname{EXT} 60 \% \mathrm{sec}$ & 20.00 & 58.00 & 40.00 & 8.00 & 64.00 & 36.00 & 0.108 \\
\hline $\mathrm{L} \mathrm{EXT} 60^{\circ} / \mathrm{sec}$ & 19.00 & 69.00 & 30.50 & 3.00 & 64.00 & 30.50 & 0.947 \\
\hline R FLEX $60^{\circ} / \mathrm{sec}$ & 4.00 & 52.00 & 13.50 & 1.00 & 33.00 & 15.50 & 0.758 \\
\hline L FLEX $60^{\circ} / \mathrm{sec}$ & 1.00 & 27.00 & 11.00 & 1.00 & 39.00 & 15.00 & 0.165 \\
\hline R EXT $90^{\circ} / \mathrm{sec}$ & 14.00 & 52.00 & 33.50 & 1.00 & 47.00 & 27.00 & 0.174 \\
\hline L EXT $90^{\circ} / \mathrm{sec}$ & 5.00 & 49.00 & 28.50 & 1.00 & 45.00 & 25.50 & 0.947 \\
\hline R FLEX $90^{\circ} / \mathrm{sec}$ & 5.00 & 56.00 & 13.00 & 1.00 & 34.00 & 15.00 & 0.925 \\
\hline L FLEX $90^{\circ} / \mathrm{sec}$ & 1.00 & 24.00 & 7.50 & 1.00 & 37.00 & 14.00 & 0.142 \\
\hline $\mathrm{R} \mathrm{EXT} 120^{\circ} / \mathrm{sec}$ & 12.00 & 47.00 & 29.50 & 1.00 & 47.00 & 23.00 & 0.369 \\
\hline L EXT $120 \%$ sec & 0.00 & 42.00 & 24.00 & 1.00 & 39.00 & 23.50 & 0.968 \\
\hline R FLEX $120 \%$ sec & 1.00 & 50.00 & 13.00 & 1.00 & 26.00 & 15.00 & 0.529 \\
\hline L FLEX $120^{\circ} / \mathrm{sec}$ & 0.00 & 22.00 & 6.50 & 0.00 & 30.00 & 14.50 & 0.149 \\
\hline $\mathrm{REXT} 180 \%$ sec & 0.00 & 43.00 & 18.00 & 0.00 & 35.00 & 18.00 & 0.495 \\
\hline L EXT $180^{\circ} / \mathrm{sec}$ & 12.00 & 43.00 & 22.00 & 1.00 & 31.00 & 15.50 & 0.076 \\
\hline R FLEX $180^{\circ} / \mathrm{sec}$ & 0.00 & 15.00 & 3.00 & 0.00 & 16.00 & 8.50 & 0.102 \\
\hline L FLEX $180^{\circ} / \mathrm{sec}$ & 0.00 & 16.00 & 5.00 & 0.00 & 16.00 & 9.50 & 0.091 \\
\hline
\end{tabular}


Table 4. Differences in the parameters between the mini-squat exercise and straight leg raises exercise groups

\begin{tabular}{|c|c|c|c|c|c|c|c|c|c|}
\hline & & \multicolumn{4}{|c|}{ MSE group } & \multicolumn{4}{|c|}{ SLRE group } \\
\hline & & Minimum & Maximum & Median & $p$ & Minimum & Maximum & Median & $p$ \\
\hline \multirow[t]{3}{*}{ TUG test (sec) } & BEP & 5.92 & 14.75 & 7.75 & & 5.97 & 25.65 & 10.12 & \\
\hline & AEP & 4.81 & 9.97 & 6.82 & $<0.001^{\star}$ & 5.00 & 13.81 & 8.52 & $0.001^{*}$ \\
\hline & $\mathrm{F}$ & 5.76 & 10.00 & 7.25 & & 5.48 & 19.80 & 7.36 & \\
\hline \multirow[t]{3}{*}{ VAS (cm) } & BEP & 0.00 & 10.00 & 7.50 & & 0.00 & 10.00 & 5.50 & \\
\hline & AEP & 0.00 & 8.00 & 1.50 & $<0.001^{*}$ & 0.00 & 10.00 & 3.00 & $<0.001^{*}$ \\
\hline & $\mathrm{F}$ & 0.00 & 7.00 & 1.00 & & 0.00 & 10.00 & 2.00 & \\
\hline \multirow[t]{3}{*}{ KOOS-PS } & BEP & 75.00 & 600.00 & 425.00 & & 175.00 & 700.00 & 437.50 & \\
\hline & AEP & 25.00 & 500.00 & 200.00 & $<0.001^{\star}$ & 0.00 & 700.00 & 312.50 & $<0.001^{*}$ \\
\hline & $\mathrm{F}$ & 0.00 & 500.00 & 200.00 & & 0.00 & 700.00 & 300.00 & \\
\hline \multirow[t]{3}{*}{ KAT } & BEP & 210.00 & 4825.00 & 546.00 & & 123.00 & 2611.00 & 634.00 & \\
\hline & AEP & 170.00 & 3518.00 & 498.50 & 0.522 & 131.00 & 6744.00 & 563.00 & 0.951 \\
\hline & $\mathrm{F}$ & 88.00 & 3791.00 & 424.00 & & 88.00 & 2492.00 & 782.00 & \\
\hline \multirow[t]{3}{*}{ R EXT $60 \%$ sec } & BEP & 14.00 & 56.00 & 32.50 & & 7.00 & 56.00 & 22.50 & \\
\hline & AEP & 20.00 & 71.00 & 43.00 & $0.029^{*}$ & 11.00 & 62.00 & 25.00 & 0.220 \\
\hline & $\mathrm{F}$ & 20.00 & 58.00 & 40.00 & & 8.00 & 64.00 & 36.00 & \\
\hline \multirow[t]{3}{*}{$\mathrm{L} \mathrm{EXT} 60 \%$ sec } & BEP & 20.00 & 62.00 & 31.00 & & 5.00 & 53.00 & 29.00 & \\
\hline & AEP & 20.00 & 72.00 & 34.50 & 0.348 & 12.00 & 64.00 & 34.00 & 0.188 \\
\hline & $\mathrm{F}$ & 19.00 & 69.00 & 30.50 & & 3.00 & 64.00 & 30.50 & \\
\hline \multirow[t]{3}{*}{ R FLEX $60 \%$ sec } & BEP & 1.00 & 50.00 & 16.00 & & 1.00 & 28.00 & 9.00 & \\
\hline & AEP & 5.00 & 53.00 & 12.00 & 0.741 & 1.00 & 33.00 & 13.50 & 0.050 \\
\hline & $\mathrm{F}$ & 4.00 & 52.00 & 13.50 & & 1.00 & 33.00 & 15.50 & \\
\hline \multirow[t]{3}{*}{ L FLEX $60^{\circ} / \mathrm{sec}$} & BEP & 1.00 & 27.00 & 15.50 & & 0.00 & 27.00 & 9.00 & \\
\hline & AEP & 1.00 & 37.00 & 12.00 & 0.909 & 1.00 & 28.00 & 16.00 & 0.050 \\
\hline & $\mathrm{F}$ & 1.00 & 27.00 & 11.00 & & 1.00 & 39.00 & 15.00 & \\
\hline \multirow[t]{3}{*}{ R EXT $90^{\circ} / \mathrm{sec}$} & BEP & 9.00 & 38.00 & 33.00 & & 4.00 & 47.00 & 19.50 & \\
\hline & AEP & 14.00 & 61.00 & 37.50 & $<0.001^{\star}$ & 0.00 & 50.00 & 20.00 & 0.744 \\
\hline & $\mathrm{F}$ & 14.00 & 52.00 & 33.50 & & 1.00 & 47.00 & 27.00 & \\
\hline \multirow[t]{3}{*}{ L EXT $90^{\circ} / \mathrm{sec}$} & BEP & 18.00 & 49.00 & 23.50 & & 4.00 & 46.00 & 21.50 & \\
\hline & AEP & 8.00 & 56.00 & 31.50 & $0.011^{*}$ & 11.00 & 53.00 & 27.00 & 0.327 \\
\hline & $\mathrm{F}$ & 5.00 & 49.00 & 28.50 & & 1.00 & 45.00 & 25.50 & \\
\hline \multirow[t]{3}{*}{ R FLEX $90^{\circ} / \mathrm{sec}$} & BEP & 3.00 & 42.00 & 14.00 & & 1.00 & 22.00 & 6.00 & \\
\hline & AEP & 1.00 & 39.00 & 13.00 & 0.750 & 0.00 & 24.00 & 8.00 & $<0.001^{*}$ \\
\hline & $\mathrm{F}$ & 5.00 & 56.00 & 13.00 & & 1.00 & 34.00 & 15.00 & \\
\hline L FLEX $90^{\circ} / \mathrm{sec}$ & BEP & 1.00 & 20.00 & 10.00 & & 0.00 & 22.00 & 7.00 & \\
\hline & AEP & 0.00 & 31.00 & 8.00 & 0.662 & 1.00 & 27.00 & 8.00 & $0.020^{*}$ \\
\hline & $\mathrm{F}$ & 1.00 & 24.00 & 7.50 & & 1.00 & 37.00 & 14.00 & \\
\hline R EXT $120^{\circ} / \mathrm{sec}$ & $\mathrm{BEP}$ & 9.00 & 42.00 & 25.00 & & 3.00 & 43.00 & 18.00 & \\
\hline & AEP & 12.00 & 54.00 & 36.00 & $<0.001^{*}$ & 0.00 & 45.00 & 20.00 & 0.064 \\
\hline & $\mathrm{F}$ & 12.00 & 47.00 & 29.50 & & 1.00 & 47.00 & 23.00 & \\
\hline L EXT $120^{\circ} / \mathrm{sec}$ & BEP & 16.00 & 42.00 & 23.00 & & 4.00 & 45.00 & 19.00 & \\
\hline & AEP & 5.00 & 46.00 & 31.00 & $0.030^{*}$ & 9.00 & 45.00 & 26.00 & 0.153 \\
\hline & $\mathrm{F}$ & 0.00 & 42.00 & 24.00 & & 1.00 & 39.00 & 23.50 & \\
\hline R FLEX $120^{\circ} / \mathrm{sec}$ & BEP & 1.00 & 24.00 & 10.00 & & 1.00 & 19.00 & 4.00 & \\
\hline & AEP & 1.00 & 39.00 & 8.00 & 0.476 & 0.00 & 18.00 & 10.00 & 0.116 \\
\hline & $\mathrm{F}$ & 1.00 & 50.00 & 13.00 & & 1.00 & 26.00 & 15.00 & \\
\hline L FLEX $120^{\circ} / \mathrm{sec}$ & BEP & 1.00 & 22.00 & 5.00 & & 0.00 & 19.00 & 5.00 & \\
\hline & AEP & 1.00 & 24.00 & 10.50 & $0.029^{*}$ & 0.00 & 20.00 & 7.00 & $0.042^{*}$ \\
\hline & $\mathrm{F}$ & 0.00 & 22.00 & 6.50 & & 0.00 & 30.00 & 14.50 & \\
\hline R EXT $180^{\circ} / \mathrm{sec}$ & BEP & 7.00 & 34.00 & 17.50 & & 4.00 & 39.00 & 15.00 & \\
\hline & AEP & 7.00 & 65.00 & 30.50 & $0.029^{*}$ & 8.00 & 34.00 & 18.50 & 0.211 \\
\hline & $\mathrm{F}$ & 0.00 & 43.00 & 18.00 & & 0.00 & 35.00 & 18.00 & \\
\hline L EXT $180^{\circ} / \mathrm{sec}$ & BEP & 9.00 & 28.00 & 18.50 & & 3.00 & 35.00 & 14.50 & \\
\hline & AEP & 1.00 & 38.00 & 23.00 & $<0.001^{*}$ & 9.00 & 42.00 & 22.00 & 0.059 \\
\hline & $\mathrm{F}$ & 12.00 & 43.00 & 22.00 & & 0.00 & 35.00 & 18.00 & \\
\hline R FLEX $180^{\circ} / \mathrm{sec}$ & BEP & 1.00 & 23.00 & 6.00 & & 0.00 & 16.00 & 4.00 & \\
\hline & AEP & 1.00 & 31.00 & 7.00 & 0.118 & 1.00 & 15.00 & 4.50 & 0.424 \\
\hline & $\mathrm{F}$ & 0.00 & 15.00 & 3.00 & & 0.00 & 15.00 & 8.50 & \\
\hline L FLEX $180^{\circ} / \mathrm{sec}$ & BEP & 0.00 & 15.00 & 7.00 & & 0.00 & 16.00 & 4.00 & \\
\hline & AEP & 1.00 & 20.00 & 6.00 & 0.591 & 0.00 & 14.00 & 4.00 & 0.598 \\
\hline & $\mathrm{F}$ & 0.00 & 16.00 & 5.00 & & 0.00 & 16.00 & 9.50 & \\
\hline
\end{tabular}


compliance with exercise at home. The study also highlighted the advantage of mini-squats with regard to quadriceps strength and functional gains in knee OA.

Bakhtiary and Fatemi ${ }^{[17]}$ found similar pain reduction and higher levels of increased strength of the quadriceps muscle in patients doing mini-squats

\begin{tabular}{|c|c|c|c|}
\hline & & MSE group & SLRE group \\
\hline & & $p$ & $p$ \\
\hline \multirow[t]{2}{*}{ TUG test (sec) } & BEP/AEP & $<0.001^{\star} \S$ & $<0.001^{\star} \S$ \\
\hline & $\mathrm{AEP} / \mathrm{F}$ & $0.015^{\star} \S$ & $0.640 \$$ \\
\hline \multirow[t]{2}{*}{ VAS (cm) } & BEP/AEP & $<0.001^{\star} \S$ & $<0.001^{\star} \S$ \\
\hline & $\mathrm{AEP} / \mathrm{F}$ & $0.200 \$$ & $0.302 \S$ \\
\hline \multirow[t]{2}{*}{ KOOS-PS } & BEP/AEP & $<0.001^{\star} \$$ & $<0.001^{\star} \S$ \\
\hline & $\mathrm{AEP} / \mathrm{F}$ & $0.004^{\star} \S$ & $0.493 \$$ \\
\hline \multirow[t]{2}{*}{ KAT } & BEP/AEP & $1.000 \#$ & $1.000 \#$ \\
\hline & $\mathrm{AEP} / \mathrm{F}$ & $1.000 \#$ & $1.000 \#$ \\
\hline \multirow[t]{2}{*}{$\mathrm{R} \mathrm{EXT} 60^{\circ} / \mathrm{sec}$} & BEP/AEP & $0.007^{*} \S$ & $0.560 \#$ \\
\hline & $\mathrm{AEP} / \mathrm{F}$ & $0.148 \S$ & $1.000 \#$ \\
\hline \multirow[t]{2}{*}{ L EXT $60 \%$ sec } & BEP/AEP & $0.495 \#$ & $0.218 \#$ \\
\hline & $\mathrm{AEP} / \mathrm{F}$ & $0.251 \#$ & $0.986 \#$ \\
\hline \multirow[t]{2}{*}{ R FLEX $60 \% \mathrm{sec}$} & BEP/AEP & $1.000 \#$ & $0.128 \#$ \\
\hline & $\mathrm{AEP} / \mathrm{F}$ & $1.000 \#$ & $0.121 \#$ \\
\hline \multirow[t]{2}{*}{ L FLEX $60 \%$ sec } & BEP/AEP & $1.000 \#$ & $0.222 \#$ \\
\hline & $\mathrm{AEP} / \mathrm{F}$ & $1.000 \#$ & $0.586 \#$ \\
\hline \multirow[t]{2}{*}{$\mathrm{R} \mathrm{EXT} 90^{\circ} / \mathrm{sec}$} & BEP/AEP & $<0.001^{\star} \S$ & $1.000 \#$ \\
\hline & $\mathrm{AEP} / \mathrm{F}$ & $0.008^{\star} \S$ & $1.000 \#$ \\
\hline \multirow[t]{2}{*}{$\mathrm{L} \mathrm{EXT} 90^{\circ} / \mathrm{sec}$} & BEP/AEP & $0.018^{\star} \S$ & 0.095\# \\
\hline & $\mathrm{AEP} / \mathrm{F}$ & $0.061 \S$ & $1.000 \#$ \\
\hline \multirow[t]{2}{*}{ R FLEX $90 \%$ sec } & BEP/AEP & $1.000 \#$ & $0.363 \S$ \\
\hline & $\mathrm{AEP} / \mathrm{F}$ & $1.000 \#$ & $0.005^{\star}$ \\
\hline \multirow[t]{2}{*}{ L FLEX $90 \%$ sec } & BEP/AEP & $1.000 \#$ & $0.034^{\star} \varsigma$ \\
\hline & $\mathrm{AEP} / \mathrm{F}$ & $0.951 \#$ & $0.018^{\star \varsigma}$ \\
\hline \multirow[t]{2}{*}{$\mathrm{R} \mathrm{EXT} 120 \% / \mathrm{sec}$} & BEP/AEP & $0.003^{\star} \S$ & $0.220 \#$ \\
\hline & $\mathrm{AEP} / \mathrm{F}$ & $0.001^{\star} \S$ & $1.000 \#$ \\
\hline \multirow[t]{2}{*}{$\mathrm{L} \mathrm{EXT} 120 \% / \mathrm{sec}$} & BEP/AEP & $0.017^{\star} \S$ & $0.109 \#$ \\
\hline & $\mathrm{AEP} / \mathrm{F}$ & $0.025^{\star} \S$ & $1.000 \#$ \\
\hline \multirow[t]{2}{*}{ R FLEX $120 \%$ sec } & BEP/AEP & $1.000 \#$ & $0.389 \#$ \\
\hline & $\mathrm{AEP} / \mathrm{F}$ & $1.000 \#$ & $0.280 \#$ \\
\hline \multirow[t]{2}{*}{ L FLEX $120^{\circ} / \mathrm{sec}$} & BEP/AEP & $0.462 \$$ & $0.086 \$$ \\
\hline & $\mathrm{AEP} / \mathrm{F}$ & $0.035^{\star} \S$ & $0.049 * \$$ \\
\hline \multirow[t]{2}{*}{$\mathrm{R} \mathrm{EXT} 180 \% / \mathrm{sec}$} & $\mathrm{BEP} / \mathrm{AEP}$ & $0.006^{*} \varsigma$ & $0.277 \#$ \\
\hline & $\mathrm{AEP} / \mathrm{F}$ & $0.006^{*} \varsigma$ & $1.000 \#$ \\
\hline \multirow[t]{2}{*}{ L EXT $180^{\circ} / \mathrm{sec}$} & BEP/AEP & $0.005^{\star} \S$ & $0.041^{\star} \#$ \\
\hline & $\mathrm{AEP} / \mathrm{F}$ & $0.327 \S$ & $0.563 \#$ \\
\hline \multirow[t]{2}{*}{ R FLEX $180^{\circ} / \mathrm{sec}$} & BEP/AEP & $1.000 \#$ & $1.000 \#$ \\
\hline & $\mathrm{AEP} / \mathrm{F}$ & $0.047^{\star} \#$ & $1.000 \#$ \\
\hline \multirow[t]{2}{*}{ L FLEX $180^{\circ} / \mathrm{sec}$} & BEP/AEP & $1.000 \#$ & $1.000 \#$ \\
\hline & $\mathrm{AEP} / \mathrm{F}$ & 1.000\# & $0.256 \#$ \\
\hline
\end{tabular}

MSE: Mini-squat exercise; SLRE: Straight leg raise exercise; TUG: Timed Up and Go; Sec: second; BEP: Before exercise program; AEP: After exercise program; F: Follow-up; VAS: Visual analog scale; Cm: centimeter; KOOS-PS: Knee injury and Osteoarhtritis Outcome Physical Function short form; KAT: Kinesthetic ability trainer; R: Right; EXT: Extensor muscles; L: Left; FLEX: Flexor muscles; $§$ Wilcoxon test; \# Bonferroni correction test ${ }^{\star} \mathrm{p}<0.05$. compared with those performing straight leg raises in the treatment of patellar chondromalacia. They also noted that the reduction in VAS scores did not change at the two-week follow-up. As we indicated previously, our exercise protocol matched this study, but there were considerable differences between the two studies. In our study, knee OA patients were included, the traditional physical therapy program was accompanied by either straight leg raises or mini-squats, and the evaluation parameters were more detailed. Based on our clinical experiments and a review of the literature, we were aware of the exercise barriers faced by OA patients; therefore, we preferred to implement an exercise protocol that consisted of only the two types of exercise. The subjects in both groups were compatible for age and body mass index (BMI), and we hypothesized that the type of exercise in and of itself might be responsible for all observed treatment effects between the MSE and SLRE groups. Despite the higher average age of our sample, their improvements in strength and pain perception after treatment and at the four-week follow-up were consistent with the aforementioned study by Bakhtiary and Fatemi. ${ }^{[17]}$

Our outcomes were examined in relation to previous reports. For example, one study which compared the effects of straight leg raises and mini-squats included patients with patella femoral pain rather than OA patients. ${ }^{[27]}$

Both Bakhtiary and Fatemi ${ }^{[17]}$ and Witvrouw et al. ${ }^{[27]}$ used straight leg raises as an open kinetic chain exercise (OKCE) and mini-squats as a closed kinetic chain exercise (CKCE) in their programs targeting knee muscles. Straight leg raises increase knee muscle strength and protect the knee without including the knee joint while mini-squats strengthen knee muscles by including the knee joint.

Since the late 1990s, CKCEs have become more important because this type of exercise has been more closely related to function than OKCEs. ${ }^{[28]}$ According to the literature, CKCEs are more functional than OKCEs because they occur in a range of motion more closely corresponding to typical daily activities. ${ }^{[2,30]}$ Also, some studies have demonstrated that the functional evaluations of the CKCE group were better than those of the OKCE group. ${ }^{[27]}$ Our study results related to the TUG test supported the literature. Functional improvement was observed in both groups, but this improvement was more significant in the MSE group. 
Knight et al. ${ }^{[31]}$ suggested that straight leg raises would be as effective as active knee extension in developing quadriceps femoris muscle strength. Although these exercises are often given to strengthen the quadriceps muscle, especially the vastus medialis, they also target the hip flexors. In a few studies in the literature, straight leg raises were preferred as an exercise for the hip joint. In one of those studies, the rectus femoris, iliacus, adductor longus, and psoas muscles demonstrated similar activity according to electromyogram (EMG) analysis. Moreover, three muscles began to contract even before the psoas muscle. ${ }^{[32]}$ Because of the bi-articular structure of the rectus femoris part of the quadriceps muscle, we preferred straight leg raises.

We looked into muscle strength changes following treatment programs, and despite a similar decrease in pain perception in both groups, the mini-squat group had increases only in the peak torques involving concentric isokinetic extension, whereas those straight leg raises group had increases only in the peak torques involving concentric isokinetic flexion. It should be noted that these parameters did not change significantly at follow-up.

We found an increase in knee extensor strength in the mini-squat group and an increase in knee flexor strength in the straight leg raises group. Gravity may be a reason for this result. In straight leg raises, as the leg is raised, the knee flexors contract eccentrically against gravity, but in mini-squats, as the knee is bent, the knee extensors contract eccentrically against gravity. Similar studies have demonstrated the existence of eccentric activity of the quadriceps muscle during mini-squats, which seems to support our opinion..$^{[17,33,34]}$

We searched for possible causes for the insufficient decrease in pain and decline in some evaluation parameters at the follow-up period and agreed that the patients' low adherence to exercise may be an important factor. Previous reports have also demonstrated that noncompliance to home exercise programs was common among OA patients. ${ }^{[15,26]}$ It has been well documented that commitment to a home exercise program is essential for maintaining the long-term benefits of exercise in OA patients and controlling the adherence to these exercises is an important responsibility for clinicians working with these patients. ${ }^{[24,35,36]}$ Unfortunately, a limitation of our study was that the exercise adherence rate was not evaluated in our sample.
Another limitation of our study was that 24 patients per group should be recruited as a sample size in order to reach $80 \%$ power. Our study only had 20 patients per group.

The literature has emphasized that $\mathrm{OA}$ is characterized by short-term fluctuations in pain and disability, ${ }^{[37]}$ and it has also been suggested that measurements in intervention studies should be frequent. ${ }^{[20]}$ Hence, if we could have repeated the measurements more frequently, perhaps the results at follow-up would have been different.

The balance index score did not change significantly after treatment in our exercise groups. In our opinion, the short treatment duration along with the choice of one single exercise for both groups may explain this result. It has been stated that the integrity and control of sensorimotor systems have important roles in maintaining balance and producing a smooth, stable gait. Thus, impairments in the function of the quadriceps muscle in knee OA may lead to a deterioration in gait and balance. ${ }^{[38,39]}$ Providing feedback from the co-contraction of the muscles on either side of the joints as well as increasing balance and proprioception are some of the superior benefits of mini-squats. ${ }^{[40,41]}$ However, the two exercise programs were not sufficient for improving the balance index scores in our study. According to a study associated with EMG results, the primary trigger signal of automatic balance corrections is provided by hip or trunk proprioceptive inputs, with knee inputs providing only a supplementary trigger signal. ${ }^{[42]}$ Knee proprioseptive training or balance training most likely would have provided additional benefits for our patients. The knee muscle strengthening exercises in our sample did not, on their own, enhance balance.

According to our results, mini-squats could be viewed as being helpful for strengthening the quadriceps muscle, and they have the advantage of providing functional progression in patients with knee OA. On the other hand, the straight leg raises group in our study saw increases in the strength of the knee flexor muscle. It has been demonstrated that quadriceps weakness is correlated with knee pain, and another study indicated that this muscle plays a crucial role in maintaining knee stability and functionality in patients with knee OA. ${ }^{[43]}$ The study by Maly et al. ${ }^{[8]}$ indicated that either quadriceps or hamstring muscle strength were very important mechanical factors related to mobility limitations 
in OA. Based on our findings and other studies in the literature, it is not possible to categorically say whether straight leg raises or mini-squats should be preferred in cases of knee OA. One recent study evaluated these two exercises in association with patellofemoral pain syndrome, and the researcher concluded that more than one treatment might be appropriate and that a patient-centered approach was favorable. ${ }^{[4]}$

In conclusion, the continuation and congruity problems of OA patients should be considered when choosing an appropriate exercise program. The physiotherapist should select the exercise type according to each patient's clinical characteristics, limitations, needs, and interests. Future research is needed regarding straight leg raises and minisquats, and this should include an evaluation of their effectiveness after long-term follow-up.

\section{Declaration of conflicting interests}

The authors declared no conflicts of interest with respect to the authorship and/or publication of this article.

\section{Funding}

The authors received no financial support for the research and/or authorship of this article.

\section{REFERENCES}

1. Reeuwijk KG, de Rooij M, van Dijk GM, Veenhof C, Steultjens MP, Dekker J. Osteoarthritis of the hip or knee: which coexisting disorders are disabling? Clin Rheumatol 2010;29:739-47.

2. Fife RS. Osteoarthritis: epidemiology, pathology and pathogenesis. In: Klippel JH, Weyand CM, Wortmann RL, editors. Primer on the rheumatic diseases. 11th ed. Atlanta: Arthritis Foundation; 1997. p. 216-7.

3. Wilson MG, Michet CJ Jr, Ilstrup DM, Melton LJ 3rd. Idiopathic symptomatic osteoarthritis of the hip and knee: a population-based incidence study. Mayo Clin Proc 1990;65:1214-21.

4. Theis KA, Helmick CG, Hootman JM. Arthritis burden and impact are greater among U.S. women than men: intervention opportunities. J Womens Health (Larchmt) 2007;16:441-53.

5. Diracoglu D, Baskent A, Celik A, Issever H, Aydin R. Long-term effects of kinesthesia/balance and strengthening exercises on patients with knee osteoarthritis: A one-year follow-up study. J Back Musculoskelet 2008;21:253-62.

6. O'Reilly SC, Jones A, Muir KR, Doherty M. Quadriceps weakness in knee osteoarthritis: the effect on pain and disability. Ann Rheum Dis 1998;57:588-94.
7. Gür H, Cakin N, Akova B, Okay E, Küçükoğlu S. Concentric versus combined concentric-eccentric isokinetic training: effects on functional capacity and symptoms in patients with osteoarthrosis of the knee. Arch Phys Med Rehabil 2002;83:308-16.

8. Maly MR, Costigan PA, Olney SJ. Contribution of psychosocial and mechanical variables to physical performance measures in knee osteoarthritis. Phys Ther 2005;85:1318-28.

9. Guccione AA, Felson DT, Anderson JJ, Anthony JM, Zhang Y, Wilson PW, et al. The effects of specific medical conditions on the functional limitations of elders in the Framingham Study. Am J Public Health 1994;84:351-8.

10. Hurley MV, Scott DL, Rees J, Newham DJ. Sensorimotor changes and functional performance in patients with knee osteoarthritis. Ann Rheum Dis 1997;56:641-8.

11. Bezalel T, Carmeli E, Katz-Leurer M. The effect of a group education programme on pain and function through knowledge acquisition and home-based exercise among patients with knee osteoarthritis: a parallel randomised single-blind clinical trial. Physiotherapy 2010;96:137-43.

12. Cetin N, Aytar A, Atalay A, Akman MN. Comparing hot pack, short-wave diathermy, ultrasound, and TENS on isokinetic strength, pain, and functional status of women with osteoarthritic knees: a single-blind, randomized, controlled trial. Am J Phys Med Rehabil 2008;87:443-51.

13. van Baar ME, Assendelft WJ, Dekker J, Oostendorp RA, Bijlsma JW. Effectiveness of exercise therapy in patients with osteoarthritis of the hip or knee: a systematic review of randomized clinical trials. Arthritis Rheum 1999;42:1361-9.

14. Røgind H, Bibow-Nielsen B, Jensen B, Møller HC, Frimodt-Møller H, Bliddal $\mathrm{H}$. The effects of a physical training program on patients with osteoarthritis of the knees. Arch Phys Med Rehabil 1998;79:1421-7.

15. O’Reilly SC, Muir KR, Doherty M. Effectiveness of home exercise on pain and disability from osteoarthritis of the knee: a randomised controlled trial. Ann Rheum Dis 1999;58:15-9.

16. Schilke JM, Johnson GO, Housh TJ, O'Dell JR. Effects of muscle-strength training on the functional status of patients with osteoarthritis of the knee joint. Nurs Res 1996;45:68-72.

17. Bakhtiary AH, Fatemi E. Open versus closed kinetic chain exercises for patellar chondromalacia. Br J Sports Med 2008;42:99-102.

18. Kellgren JH, Lawrence JS. Radiological assessment of osteo-arthrosis. Ann Rheum Dis 1957;16:494-502.

19. Podsiadlo D, Richardson S. The timed "Up \& Go": a test of basic functional mobility for frail elderly persons. J Am Geriatr Soc 1991;39:142-8.

20. Jordan KP, Wilkie R, Muller S, Myers H, Nicholls E; Arthritis Research Campaign National Primary Care Centre. Measurement of change in function and disability in osteoarthritis: current approaches and future challenges. Curr Opin Rheumatol 2009;21:525-30. 
21. Perruccio AV, Stefan Lohmander L, Canizares M, Tennant A, Hawker GA, Conaghan PG, et al. The development of a short measure of physical function for knee OA KOOS-Physical Function Shortform (KOOS-PS) - an OARSI/OMERACT initiative. Osteoarthritis Cartilage 2008;16:542-50.

22. Paker N, Bugdaycı D, Sabırlı F, Ozel S, Ersoy S. Knee Injury and osteoarthritis outcome score: reliability and validation of the Turkish version. Turk Klin J Med Sci 2007;27:350-6.

23. Roddy E, Zhang W, Doherty M, Arden NK, Barlow J, Birrell $\mathrm{F}$, et al. Evidence-based recommendations for the role of exercise in the management of osteoarthritis of the hip or knee-the MOVE consensus. Rheumatology (Oxford) 2005;44:67-73.

24. Stitik TP, Gazzillo G, Foye PM. Osteoarthritis and therapeutic exercise. Am J Lifestyle Med 2007;1:360-6.

25. Bennell KL, Hinman RS. The role of resistance training in the management of knee osteoarthritis. European Musculoskeletal Review 2011;6:10-3.

26. Petrella RJ, Bartha C. Home based exercise therapy for older patients with knee osteoarthritis: a randomized clinical trial. J Rheumatol 2000;27:2215-21.

27. Witvrouw E, Danneels L, Van Tiggelen D, Willems TM, Cambier D. Open versus closed kinetic chain exercises in patellofemoral pain: a 5-year prospective randomized study. Am J Sports Med 2004;32:1122-30.

28. Beynnon BD, Johnson RJ, Fleming BC, Stankewich CJ, Renström PA, Nichols CE. The strain behavior of the anterior cruciate ligament during squatting and active flexion-extension. A comparison of an open and a closed kinetic chain exercise. Am J Sports Med 1997;25:823-9.

29. Bynum EB, Barrack RL, Alexander AH. Open versus closed chain kinetic exercises after anterior cruciate ligament reconstruction. A prospective randomized study. Am J Sports Med 1995;23:401-6.

30. Steinkamp LA, Dillingham MF, Markel MD, Hill JA, Kaufman KR. Biomechanical considerations in patellofemoral joint rehabilitation. Am J Sports Med 1993;21:438-44.

31. Knight KL, Martin JA, Londeree BR. EMG comparison of quadriceps femoris activity during knee extension and straight leg raises. Am J Phys Med 1979;58:57-67.

32. Hu H, Meijer OG, van Dieën JH, Hodges PW, Bruijn SM, Strijers RL, et al. Is the psoas a hip flexor in the active straight leg raise? Eur Spine J 2011;20:759-65.
33. Stiene HA, Brosky T, Reinking MF, Nyland J, Mason MB. A comparison of closed kinetic chain and isokinetic joint isolation exercise in patients with patellofemoral dysfunction. J Orthop Sports Phys Ther 1996;24:136-41.

34. Jonsson P, Alfredson H. Superior results with eccentric compared to concentric quadriceps training in patients with jumper's knee: a prospective randomised study. Br J Sports Med 2005;39:847-50.

35. Jensen GM, Lorish CD. Promoting patient cooperation with exercise programs: linking research, theory, and practice. Arthritis Care Res 1994;7:181-9.

36. Ettinger WH Jr, Burns R, Messier SP, Applegate W, Rejeski WJ, Morgan $\mathrm{T}$, et al. A randomized trial comparing aerobic exercise and resistance exercise with a health education program in older adults with knee osteoarthritis. The Fitness Arthritis and Seniors Trial (FAST). JAMA 1997;277:25-31.

37. Hutchings A, Calloway M, Choy E, Hooper M, Hunter DJ, Jordan JM, et al. The Longitudinal Examination of Arthritis Pain (LEAP) study: relationships between weekly fluctuations in patient-rated joint pain and other health outcomes. J Rheumatol 2007;34:2291-300.

38. Fitzpatrick R, McCloskey DI. Proprioceptive, visual and vestibular thresholds for the perception of sway during standing in humans. J Physiol 1994;478:173-86.

39. Lord SR, Lloyd DG, Li SK. Sensori-motor function, gait patterns and falls in community-dwelling women. Age Ageing 1996;25:292-9.

40. Vad V, Hong HM, Zazzali M, Agi N, Basrai D. Exercise recommendations in athletes with early osteoarthritis of the knee. Sports Med 2002;32:729-39.

41. Fleming BC, Oksendahl H, Beynnon BD. Open- or closedkinetic chain exercises after anterior cruciate ligament reconstruction? Exerc Sport Sci Rev 2005;33:134-40.

42. Bloem BR, Allum JH, Carpenter MG, Verschuuren JJ, Honegger F. Triggering of balance corrections and compensatory strategies in a patient with total leg proprioceptive loss. Exp Brain Res 2002;142:91-107.

43. Baker K, Xu L, Zhang Y. Quadriceps weakness and its relation to tibio femoral and patellofemoral knee osteoarthritis in men and women. Arthritis Rheum 2001;44:226.

44. Carlson J, Hobbs L, Smith K. Isolation of the Vastus Medialis Oblique muscle during semi-squat and straight leg raise exercises. The Plymouth Student Journal of Health and Social Work 2010;2:40-53. 